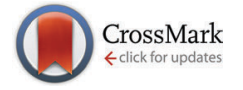

Cite this: Phys. Chem. Chem. Phys., 2016, 18, 13717

DOI: $10.1039 / c 6 c p 90115 h$

www.rsc.org/pccp

\section{Correction: Are stabilizing osmolytes preferentially excluded from the protein surface? FTIR and MD studies}

\author{
P. Bruździak,* B. Adamczak, E. Kaczkowska, J. Czub and J. Stangret
}

Correction for 'Are stabilizing osmolytes preferentially excluded from the protein surface? FTIR and MD studies' by P. Bruździak et al., Phys. Chem. Chem. Phys., 2015, 17, 23155-23164.

The authors would like to update the information provided in the Acknowledgements.

The sentence:

"This work was supported from the Republic of Poland scientific funds as a research project within Grant No. 2013/11/B/NZ1/ 02258."

should be rewritten as:

"This work was supported from the Polish National Science Centre (NCN) based on the decision DEC-2013/11/B/NZ1/02258." The Royal Society of Chemistry apologises for these errors and any consequent inconvenience to authors and readers. 